\title{
MODERN ANALYSIS METHODS USE IN ORDER TO ESTABLISH THE GEOGRAPHIC ORIGIN OF FOOD PRODUCTS
}

\author{
Lev A. Oganesyants, Alexander L. Panasyuk, Elena I. Kuzmina*, Dmitriy A. Sviridov
}

All-Russian Scientific Research Institute of the Brewing, Non-Alcoholic and Wine Industry -

Branch of the V. M. Gorbatov Federal Research Center for Food Systems of Russian Academy of Sciences, Moscow, Russia

\section{KEY WORDS:}

controlled origin place, isotopic mass spectrometry, elemental profile, stable isotope ratio

\begin{abstract}
Food products with controlled geographical origin place are in special demand among consumers because of their specific properties, due to climatic, soil characteristics or other factors. The article provides an analysis of regulatory framework for legal goods protection with an indication of their origin place on the territory of the Russian Federation and in other countries. Existing authentication methods for this type of product are reviewed. Based on the analysis of scientific literature, the authors noted the most significant works aimed at confirming the authenticity of food products' origin place on the example of honey and meat products, which were carried out in the countries of the European Union, Australia, China, Brazil, South Africa, the USA and other countries. It is shown that the most widespread researches aimed at studying values of isotopic ratios of hydrogen $\left({ }^{2} \mathrm{H} /{ }^{1} \mathrm{H}\right)$, carbon $\left({ }^{13} \mathrm{C} /{ }^{12} \mathrm{C}\right)$, oxygen $\left({ }^{18} \mathrm{O} /{ }^{16} \mathrm{O}\right)$, nitrogen $\left({ }^{15} \mathrm{~N} /{ }^{14} \mathrm{~N}\right)$ and sulfur $\left({ }^{34} \mathrm{~S} /{ }^{32} \mathrm{~S}\right)$ in compounds contained in products that reflect the distribution of «light» and «heavy» isotopes during biological and geochemical processes within a single region. The analysis of the works aimed at studying the qualitative and quantitative composition of trace elements and rare earth metals (As, B, Ba, Cd, Li, Mn, Pd, Rb, Se, Te, Tl, Dy, U, etc.), as well as research of isotopic relations values of some elements ${ }^{87} \mathrm{Sr} /{ }^{86} \mathrm{Sr},{ }^{207} \mathrm{~Pb} /{ }^{206} \mathrm{~Pb}$, etc.) in product samples and soils of studied region. The advantages of an integrated research approach, which includes the creation of data array of various indicators values and its in-depth analysis using chemometric algorithms and mathematical modeling methods, are shown.
\end{abstract}

\section{Introduction}

Food production previously, as a rule, was inextricably linked to specific geographic region. Food products were produced from local raw materials using traditional technologies and sold on local market. Such products were an integral part of culture and people life.

Today, as a result of market globalization, with all goods availability and variety, the food industry is experiencing a confidence crisis. The consumer wants to be sure of purchased products safety, its high quality and environmental production friendliness. The food production with a controlled origin place is subject to more stringent requirements, which ensures its high quality and uniqueness. However, there remains food products falsification danger of protected origin place by substituting finished products or raw materials with products or raw materials from other geographical regions. In this regard, researches aimed at confirming geographical food products' origin place are widely used in order to protect producers from unfair competition.

\section{Main part}

Such phrases as «English tea», «Belgian chocolate» are products of market globalization and do not fully guarantee the constancy of taste characteristics. The consumer's desire to be confident in food products authenticity is increasing, which entails growing role of the institute for items protection at the origin place. The Civil Code gives the following definition of this concept:

the name of the origin place of goods to which legal protection is granted is a designation that is either containing a modern or historical, official or unofficial, full or abbreviated name of a country, urban or rural settlement, locality or other geographical object, as well as a designation derived from such an appellation and which became known as a result of its use in relation to a product whose special properties are exclusively or mainly determined by characteristic of geographical natural conditions and (or) human factors. The exclusive manufacturers' right of such goods may be recognized on the use of this name [1].
In contrast to trademark, the name of goods' origin place performs in addition to the distinctive function of guaranteeing certain properties of the goods, as a result of which its additional attractiveness to consumers is ensured. Considering that such goods can be produced by an indefinite number of business entities, the Code provides exclusive rights for all goods producers.

The impetus for protected denomination system creation was the unrest in the province of Bordeaux (France), when local winegrowers demanded government to put up a barrier to counterfeiters in the south of France, who mass-produced products under the Bordeaux brand. At the same time, the state also pursued a fiscal goal, for implementation of which, Napoleon Bonaparte in 1804 signed a law on the organization of indirect taxes on wine and alcoholic beverages.

But only in 1935 a decree was signed establishing the National Committee of Wines and Spirits, which in 1947 was reorganized into The National Institute of Origin and Quality (INAO). Since 1990, the Institute has expanded its activities to other types of food products. Figure 1 shows the INAO data on the ratio of number of different types of food products (except wine) of protected designation of origin (PDO) and protected geographical indication (PGI) produced in the EU countries.

Figure 1. The ratio of food products' types number (except wine products) PDO and PGI in the EU countries

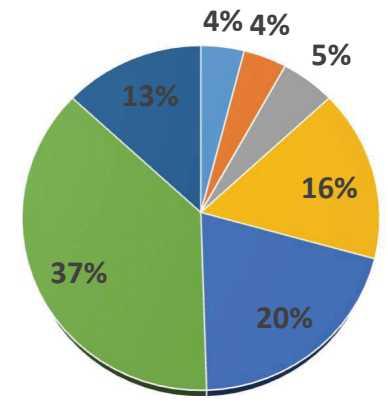
- Bakery and confectionery

- Vegetables and fruits

- Fresh meat

Meat products

- Beer

- Cheeses

- Others 
As for wines and other alcoholic beverages, their number exceeded three thousand. In the countries of the European Union, their production is regulated by Regulation (EU) No. 607/2009 of the Commission of July 14, 2009. Many countries use their national quality labels to classify wines according to their geographical location $[2,3,4,5,6]$. Figure 2 shows the differences in product requirements for $\mathrm{PDO}$ and $\mathrm{PGI}$ categories.

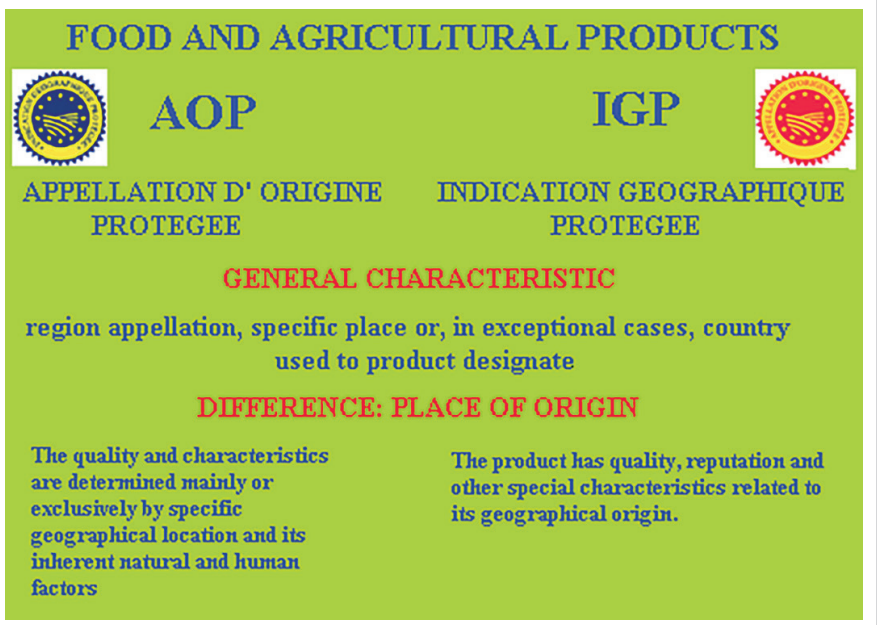

Figure 2. Differences in product requirements for PDO (AOP) and PGI (IGP) categories

On the territory of the Russian Federation, legal relations in this area are regulated by law and register of goods designation of origin of the Russian Federation is maintained. Well-known products include Vologodskoye maslo (Vologda oil), Narzan (Narzan), Bashkirsky myod (Bashkir honey), Yaroslavsky syr (Yaroslavl cheese), Tulsky pryanik (Tula gingerbread), Kolomenskaya pastila (Kolomna pastila), Tambovsky okorok (Tambov ham), Astrakhansky arbuz (Astrakhan watermelon) [7, 8].

In Russia, the All-Russian Research Institute of Brewing, Beverage and Wine Industry took the initiative to create a wine protection system with an origin appellation. As a result, the national standard GOST R55242-2012 «Wines of protected geographical indication and protected designation of origin. PAS», interstate standards GOST 32715-2014 «Liqueur wines, liquor wines of protected geographical indication and liquor wines of protected designation of origin. PAS», as well as GOST 33336-2015 «Sparkling wines, PAS», which also shows the division for these quality categories, was developed and approved.

Federal Law No. 171-FZ «On State Regulation of the Production and Turnover of Ethyl Alcohol, Alcohol and Alcohol-Containing Products and on the Limitation of the Consumption (Drinking) of Alcoholic Products» gives the following definitions for wines with controlled place of origin:

wine products with protected geographical indication - wine products, production of which, including bottling, is carried out within the boundaries of a geographical object indicated on various labels types (label, collar label, counter-label), consumer container (package), and which is made from grape varieties or grape varieties mixtures specified by technical documents and has properties that are determined by natural conditions characteristic of given geographical object. Wine production with protected geographical indication is made from grapes, at least 85 percent of which is grown within the boundaries of given geographical object, and the rest used for production of such products which is grown within the boundaries of the subject of the Russian Federation where this geographical object is located;

wine products with protected designation of origin - wine products, production of which, including bottling, is carried out within the boundaries of a geographical object indicated on various labels types (label, collar label, counter-label), consumer container (package), and which is made from grape varieties or grape varieties mixtures specified by technical documents, growing and processed within the boundaries of a given geographical object, and has properties that are determined by natural conditions and (or) human factors, used agro-technical measures and technological methods that are characteristic for given geographical object.

The issue of regional identification is also relevant for mineral waters. One of the main methods of mineral waters falsification is to indicate a nonexistent source or to indicate a source that is not included in the Register of deposits.

Identifying the origin of food is an important element in ensuring its safety and quality control. In world practice, product identification at the place of geographical origin is carried out, as a rule, with help of comprehensive elemental profile research, the values of isotopic characteristics and chemometric methods of results processing.

Methods for determining the ratios of stable hydrogen isotopes $\left({ }^{2} \mathrm{H} /{ }^{1} \mathrm{H}\right)$, carbon $\left({ }^{13} \mathrm{C} /{ }^{12} \mathrm{C}\right)$, oxygen $\left({ }^{18} \mathrm{O} /{ }^{16} \mathrm{O}\right)$, nitrogen $\left({ }^{15} \mathrm{~N} /{ }^{14} \mathrm{~N}\right)$ and sulfur $\left({ }^{34} \mathrm{~S} /{ }^{32} \mathrm{~S}\right)$ are actively used in raw materials identification at the place of its geographical origin. The distribution of stable isotopes of biophilic elements in different biological and abiotic systems varies significantly. Distribution features are associated with fractionation processes, that is, with change in the ratio of «light» and «heavy» isotopes during biological and geochemical processes $[9,10]$. In research of food products for regional identification, an important role is played by carbon isotopes fractionation in photosynthesis, the nitrogen isotopes fractionation in organic compounds destruction, the oxygen and hydrogen isotopes fractionation in water under abiotic factors, and in plants and animals metabolism. To obtain the values of biophilic elements isotopic characteristics, isotope ratio mass spectrometry (IRMS) and nuclear magnetic resonance (NMR) methods are used $[11,12,13]$.

The trace element composition of the soil depends on a number of unique factors (soil $\mathrm{pH}$, moisture, the presence of clay and humic complexes, etc.) [14]. The elemental profile of plant tissues is inextricably linked with soil composition of the place where it grow, which in turn forms the elemental composition of pasture animals tissues in this region. Thus, the research of qualitative and quantitative composition of micro- and rare-earth elements, as well as the ratio of certain atoms stable isotopes (strontium, cesium, lead) contained in the soil, can provide information on the geographical origin of a number of food products. To study the elemental profile, methods are used such as inductively coupled plasma mass spectrometry (ICP-MS), atomic absorption spectrometry (AAS), inductively coupled plasma atomic emission spectrometry (ICP-AES), flame atomization absorption spectrophotometry (FAAS), neutron activation analysis (NAA), X-ray fluorescence analysis (XRF) $[15,16,17,18,19]$.

Use of chemometric algorithms allow to identify interlinkages between obtained values and evaluate the contribution of each of them to power identification of the statistical model. This approach is relevant in establishing criteria for authenticity of products and raw materials geographical location, since most methods use large data amounts. The most commonly used analysis of variance (ANOVA), principal component analysis (PCA), linear discriminant analysis (LDA), method of soft independent modeling of class analogy (SIMCA), support vector method (SVM), cluster analysis (CA), classification and regression trees (CARTs), the method of k-nearest neighbors $(\mathrm{kNN})$, the method of partial least squares (PLS), artificial neural networks (ANN) [20,21,22].

The described methods are widely used in world practice. Currently, in many countries, large-scale researches of food products are carried out in order to establish its geographical origin place. We have already provided information on the use of these methods in winemaking [23]. In the framework of this article, 
actual methods for identifying the geographical origin of one of the most popular products, namely meat products, dairy products and honey, are considered.

In studies aimed at establishing the geographical origin place of cattle and meat products, the analysis of stable carbon, hydrogen and nitrogen isotopes ratios is most often used. As described above, elements with an isotopic composition specific to a given region accumulate in plants and animals' tissues, that uses as food [24,25,26,27,28,29].

However, the establishment of geographical origin place authenticity of meat products by isotope ratio mass spectrometry can be complicated by a number of factors. For example, farm animals can be raised on different farms throughout their lives, they can consume feed of various origins, and it has also been established that isotopic composition of animal tissues biophilic elements may have seasonal deviations [30].

In order to establish the geographical origin place, 120 mutton samples, produced in various regions of Great Britain, Spain, France, Greece, Iceland and Italy were analyzed. The obtained ratios of the isotope ${ }^{15} \mathrm{~N} /{ }^{14} \mathrm{~N},{ }^{13} \mathrm{C} /{ }^{12} \mathrm{C}$ were processed using discriminant analysis. Thus, $79.2 \%$ of mutton samples were identified accurately [31].

Chinese researchers studied 167 beef hair samples from four regions of China. By values of isotopes ratios ${ }^{2} \mathrm{H} /{ }^{1} \mathrm{H},{ }^{15} \mathrm{~N} /{ }^{14} \mathrm{~N},{ }^{13} \mathrm{C} /{ }^{12} \mathrm{C}$, $82.6 \%$ of samples were accurately identified by region [32].

Using the same indicators, South African scientists were able to accurately identify $97.6 \%$ of Karoo mutton samples from the Karoo region that fed on the region's fragrant plants [10].

In order to study the relations characteristics of stable carbon and nitrogen isotopes in meat, a large-scale study of 599 pork samples of various origin from 14 countries was conducted in South Korea: 335 samples from South Korea, 264 from South and North America (Canada, USA, Mexico, Chile), 9 - from European countries (Austria, Holland, Denmark, France, Belgium, Finland, Poland, Hungary, Spain). The ratio of stable isotope ${ }^{13} \mathrm{C} /{ }^{12} \mathrm{C}$ and ${ }^{15} \mathrm{~N} /{ }^{14} \mathrm{~N}$ in proteins of fat-free dry pork residue was studied. The analysis showed a clear separation in the origin of meat from three regions: South Korea, America and Europe. Researchers also identified similar $\delta^{13} \mathrm{C}$ results for the USA and Mexico: minus $14.78 \%$ and minus $14.81 \%$, respectively, for Holland and Denmark: minus $25.57 \%$ and minus $25.24 \%$ o, respectively, due to their geographical proximity [33].

The feasibility of studying the values of isotopes ratios of light elements to establish the geographical origin place of beef from Japan, Australia, the United States, and EU countries has also been confirmed by number of researches [34,35,36].

Researchers from Switzerland identified 72 elements in 78 samples of poultry meat and 74 samples of dried beef from various regions of the world. By the elements ${ }^{75} \mathrm{As},{ }^{23} \mathrm{Na},{ }^{85} \mathrm{Rb},{ }^{77} \mathrm{Se},{ }^{88} \mathrm{Sr},{ }^{20}$ ${ }^{5} \mathrm{Tl}$, researchers were able to distinguish poultry meat from Brazil, France, Germany, Hungary, and Switzerland with high accuracy. Samples of dried beef were identified by elements ${ }^{75} \mathrm{As},{ }^{10} \mathrm{~B},{ }^{137} \mathrm{Ba},{ }^{4}$ ${ }^{2} \mathrm{Ca},{ }^{111} \mathrm{Cd},{ }^{63} \mathrm{Cu},{ }^{163} \mathrm{Dy},{ }^{167} \mathrm{Er},{ }^{57} \mathrm{Fe},{ }^{7} \mathrm{Li},{ }^{55} \mathrm{Mn},{ }^{104} \mathrm{Pd},{ }^{85} \mathrm{Rb},{ }^{77} \mathrm{Se},{ }^{88} \mathrm{Sr},{ }^{128} \mathrm{Te},{ }^{203}$ $\mathrm{Tl},{ }^{238} \mathrm{U}$ and ${ }^{51} \mathrm{~V}$ for samples from Australia, Austria, Switzerland, Canada, Brazil, and the United States [37,38].

The isotopic characteristics of biophilic elements in milk composition, as well as other products of animal origin, largely depend on specific characteristics of the feed $[39,40,41,42,43,44]$. Consequently, milk from cows, grazing on pastures of a certain geographical region will have unique isotopic composition and elemental profile characteristic to this zone [45].

In Australia, a research was conducted on cow's milk samples from various farms to determine their regional affiliation. In milk samples from pasture cows from seven different regions of Australia and New Zealand, the ratios of stable isotope ${ }^{13} \mathrm{C} /{ }^{12} \mathrm{C},{ }^{15} \mathrm{~N} /{ }^{14} \mathrm{~N},{ }^{18} \mathrm{O}$ $/{ }^{16} \mathrm{O},{ }^{34} \mathrm{~S} /{ }^{32} \mathrm{~S}$ and ${ }^{87} \mathrm{Sr} /{ }^{86} \mathrm{Sr}$ were studied. According to the research results for each region, their unique isotopic characteristics were revealed, which allows to identify the regional milk affiliation with high accuracy. The authors noted that milk samples from Australia were enriched with heavy isotopes ${ }^{18} \mathrm{O}$ and ${ }^{34} \mathrm{~S}$ compared with recorded values for most European dairy products [47].

The research of 189 milk samples from various regions of the Netherlands, Germany, France, Austria, Hungary, Bulgaria and Belgium was conducted. The researches were carried out using isotope ratio mass spectrometry (IRMS), near infrared spectrometry (NIRS), gas chromatography with a flame ionization detector (GC-FID). The combination of methods into partial least squares discriminant analysis (PLS-DA) allowed to reliably differentiate samples according to their geographical origin with an accuracy of $95 \%$ [47].

Chinese scientists examined 42 milk samples from the USA, Canada, China, Australia, and New Zealand in order to determine their geographical origin based on the analysis of isotopes ratios ${ }^{2} \mathrm{H} /{ }^{1} \mathrm{H},{ }^{18} \mathrm{O} /{ }^{16} \mathrm{O}$ using isotope ratio mass spectrometry (IRMS). The researched parameters of isotopic characteristics of water samples component, in most cases, varied significantly depending on their geographical origin place. However, this method could not establish a difference between milk samples from northern China and New Zealand [48].

In the UK, research of stable isotope ratios ${ }^{13} \mathrm{C} /{ }^{12} \mathrm{C},{ }^{15} \mathrm{~N} /{ }^{14} \mathrm{~N},{ }^{18} \mathrm{O}$ $/{ }^{16} \mathrm{O},{ }^{2} \mathrm{H} /{ }^{1} \mathrm{H}$ of animal feed and milk on two farms was conducted. The animal diet consisted of various plants types of type C3 and different corn amount. It was shown that $\delta^{13} \mathrm{C}$ values in casein and milk lipids correlate with corn percentage in animal diet. On the other hand, the $\delta^{18} \mathrm{O}$ values of aqueous milk component and the $\delta^{18} \mathrm{O}, \delta \mathrm{D}$, and $\delta^{5} \mathrm{~N}$ values of casein only slightly depend on corn amount in the feed, as they are probably more closely related to geoclimatic and soil characteristics of origin region and to presence of fresh plants or silage in the diet [49].

In another work, scientists from Slovenia researched the values of isotope ratios ${ }^{13} \mathrm{C} /{ }^{12} \mathrm{C},{ }^{15} \mathrm{~N} /{ }^{14} \mathrm{~N},{ }^{18} \mathrm{O} /{ }^{16} \mathrm{O},{ }^{34} \mathrm{~S} /{ }^{32} \mathrm{~S}$ and the elemental profile for determining the regional origin of 124 milk samples and 30 cheese samples from different regions of Slovenia. The discriminant analysis revealed the elements $\mathrm{Cl}, \mathrm{Zn}, \mathrm{P}, \mathrm{Ca}, \mathrm{K}$ and $\delta^{13} \mathrm{C}$ and $\delta^{15} \mathrm{~N}$ as the most significant parameters. The accuracy of the correct differentiation of samples was $97 \%$. In addition, the method of studying stable isotopes in combination with elemental composition made it possible to distinguish sheep and goat milk and cheese from obtained from cow's milk with an accuracy of 95.2\% [50]. Scientists from South Korea, using indicators $\delta^{13} \mathrm{C}$ and $\delta^{15} \mathrm{~N}$ were able to accurately distinguish samples of organic milk from dairy plant milk. As in the case of meat products, the authors noted seasonal variation in the values of indicators [51].

The honey geographical affiliation is one of the main pricing factors. Honey consists of various sugars (mainly fructose and glucose), water, in addition, honey consists of proteins, free amino acids, minerals, enzymes, vitamins, organic acids and phenolic compounds $[52,53,54,55,56,57,58]$. Although many of these compounds are contained in small quantities, it is them that determine the individuality and specific honey characteristics. The biochemical honey composition, in turn, depends mainly on geographical and botanical origin, seasonal and environmental factors, and bees' species which involved in its production [59.60.61].

The largest research to determine honey geographical origin was carried out in the framework of the TRACE project, funded by the European Union. From the 20 European regions with different climatic and geological characteristics, 516 honey samples were selected. In researched samples, the isotopes ratios ${ }^{2} \mathrm{H} /{ }^{1} \mathrm{H},{ }^{15} \mathrm{~N} /{ }^{14} \mathrm{~N}$ $,{ }^{13} \mathrm{C} /{ }^{12} \mathrm{C},{ }^{34} \mathrm{~S} /{ }^{32} \mathrm{~S}$ were determined. Results processing was carried out using various chemometric methods. For 7 out of 20 regions, the accuracy of identification exceeded 70\% [62].

Scientists from the USA have developed a method for determining honey geographical origin based on protein compounds 
study using MALDI-TOF mass spectrometry method. Researchers have determined protein mass spectra for 16 samples of Hawaiian honey. According to the obtained data, it was possible to accurately distinguish the Hawaiian Islands honey samples from other regions honey [63].

The geographical origin of three Slovenian honey samples was determined using total reflectance X-ray fluorescence (TXRF) methods and isotopic ratio mass spectrometry (IRMS). For three years, 122 honey samples were collected from beekeepers from all Slovenia regions. The selected parameters made it possible to distinguish samples from four Slovenian natural and geographical regions with an accuracy of $94.6-100 \%$ depending on honey type [64]. Over the years, researchers studied the elemental composition of 30 to 140 honey samples from 16 Poland regions. Using inductively coupled plasma mass spectrometry (ICP-MS) and flame atomization absorption spectrophotometry (FAAS), 15 elements ( $\mathrm{Al}, \mathrm{B}, \mathrm{Ba}, \mathrm{Ca}, \mathrm{Cd}, \mathrm{Cr}, \mathrm{Cu}, \mathrm{K}, \mathrm{Mg}, \mathrm{Mn}, \mathrm{Na}, \mathrm{Ni}, \mathrm{Pb}, \mathrm{Sr}$ and $\mathrm{Zn}$ ) were determined in honey samples. Researches have shown significant differences in mineral composition of honey samples from different regions, which can be used to establish the geographical origin place $[15,16,17]$.
Despite the fact that values of such isotopic ratios as ${ }^{87} \mathrm{Sr} /{ }^{86} \mathrm{Sr}$, ${ }^{207} \mathrm{~Pb} /{ }^{206} \mathrm{~Pb},{ }^{208} \mathrm{~Pb} /{ }^{206} \mathrm{~Pb}$, and ${ }^{204} \mathrm{~Pb} /{ }^{206} \mathrm{~Pb}$ are also quite informative indicators when determining food products territorial affiliation, their scientists use much less often [65].

\section{Conclusion}

The results of numerous researches show that studying isotopic ratios of the main biophilic elements and elemental profile are powerful tools in confirming geographical origin place of food products. The values of isotopic ratios of hydrogen $\left({ }^{2} \mathrm{H} /{ }^{1} \mathrm{H}\right)$, carbon $\left({ }^{13} \mathrm{C} /{ }^{12} \mathrm{C}\right)$, oxygen $\left({ }^{18} \mathrm{O} /{ }^{16} \mathrm{O}\right)$, nitrogen $\left({ }^{15} \mathrm{~N} /{ }^{14} \mathrm{~N}\right)$ and sulfur $\left({ }^{34} \mathrm{~S} /{ }^{32} \mathrm{~S}\right)$ in compounds that make up food products are largely determined by climatic and geographical conditions of raw materials growth region. The qualitative and quantitative composition of trace elements and rare-earth metals (As, B, Ba, Cd, Li, Mn, Pd, Rb, Se, Te, $\mathrm{Tl}, \mathrm{Dy}, \mathrm{U}$, etc.), as well as values of isotopic ratios of some metals ${ }^{87} \mathrm{Sr} /{ }^{86} \mathrm{Sr},{ }^{207} \mathrm{~Pb} /{ }^{206} \mathrm{~Pb}$, etc.) reflect the specific terroir of researched region. Using the described research methods in combination with the methods of mathematical results processing (ANOVA, PCA, LDA, etc.) allows to confirm with high accuracy of the product belongs to specific geographical region.

\section{REFERENCES}

1. Civil code of the Russian Federation. Part four: Federal law No. 230-FZ of 18.12.2006 / SOBR. legislation of the Russian Federation. 2006. Article 1516. (in Russian)

2. Camin, F., Dordevic, N., Wehrens, R., Neteler, M., Delucchi, L., Postma, G., Buydens, L. (2015). Climatic and geographical dependence of the H, C and O stable isotope ratios of Italian wine. Analytica Chimica Acta, 853(1), 384-390. https://doi.org/10.1016/j.aca.2014.09.049

3. Dutra, S.V., Adami, L., Marcon, A.R., Carnieli, G.J., Roani, C.A., Spinelli, F.R., Leonardelli, S., Vanderlinde, R. (2013). Characterization of wines according the geographical origin by analysis of isotopes and minerals and the influence of harvest on the isotope values. Food Chemistry, 141(3), 2148-2153. https://doi.org/10.1016/j.foodchem.2013.04.106

4. Dordevic, N., Wehrens, R., Postma, G.J., Buydens, L.M.C., Camin, F. (2012). Statistical methods for improving verification of claims of origin for Italian wines based on stable isotope ratios. Analytica Chimica Acta, 757, 19-25. https://doi.org/10.1016/j.aca.2012.10.046

5. Camin, F., Bontempo, L., Perini, M., Tonon, A., Breas, O., Guillou, C., Moreno-Rojas, J.M., Gagliano, G. (2013). Control of wine vinegar authenticity through $\delta 180$ analysis. Food Control, 29(1), 107-111. https://doi. org/10.1016/j.foodcont.2012.05.055

6. Scheidegger, Y., Saurer, M., Bahn, M., Siegwolf, R. (2000). Linking stable oxygen and carbon isotopes with stomatal conductance and photosynthetic capacity: A conceptual model. Oecologia, 125(3), 350-357. https://doi.org/10.1007/s004420000466

7. Gorlenko, S.A. (2010). Protection of appellations of origin: actual issues. Patents and Licenses, 3, 2-9. (in Russian)

8. Eremenko, V.I. (2012). On the legal aspects of the protection of appellations of origin of goods in the Russian Federation. Intellectual Property Exchange, 11(2), 8-18. (in Russian)

9. Galimov, E.M. (1981). The nature of the biological fractionation of isotopes. Moscow: The science. -247 p. (in Russian)

10. 10.Erasmus, S.W., Muller, M., Van Der Rijst, M., Hoffman, L.C. (2016) Stable isotope ratio analysis: A potential analytical tool for the authentication of South African lamb meat. Food Chemistry, 192, 997-1005. https://doi.org/10.1016/j.foodchem.2015.07.121

11. Nečemer, M., Potočnik, D., Ogrinc, N. (2016). Discrimination between Slovenian cow, goat and sheep milk and cheese according to geographical origin using a combination of elemental content and stable isotope data. Journal of Food Composition and Analysis, 52, 16-23. https://doi. org/10.1016/j.jfca.2016.07.002

12. Chung, I.-M., Park, I., Yoon, J.-Y., Yang, Y.-S., Kim, S.-H. (2014). Determination of organic milk authenticity using carbon and nitrogen natural isotopes. Food Chemistry, 160, 214-218. https://doi.org/10.1016/j.foodchem.2014.01.061

13. Oganesyants, L. A., Panasyuk, A. L., Kuzmina, E. I., Yalanetskii, A. Ya., Zagorouiko, V. A. (2017). Ratio variations of ethanol carbon isotopes in wines based on vineyard geographical location. Magarach. Viticulture and Winemaking, 4, 38-40. (in Russian)

14. Jyoti, V., Saini-Eidukat, B., Hopkins, D., DeSutter, T. (2015). Naturally elevated metal contents of soils in northeastern North Dakota, USA, with a focus on cadmium. Journal of Soils and Sediments, 15(7), 1571-1583. https://doi.org/10.1007/s11368-015-1122-6
15. Chudzinska, M., Baralkiewicz, D. (2010). Estimation of honey authenticity by multielements characteristics using inductively coupled plasma-mass spectrometry (ICP-MS) combined with chemometrics. Food and Chemical Toxicology, 48(1), 284-290. https://doi.org/10.1016/j.fct.2009.10.011

16. Madejczyk, M., Baralkiewicz, D. (2008). Characterization of Polish rape and honeydew honey according to their mineral contents using ICP-MS and F-AAS/AES. Analytica Chimica Acta, 617(1-2), 11-17. https://doi. org/10.1016/j.aca.2008.01.038

17. Chudzinska, M., Baralkiewicz, D. (2011). Application of ICP-MS method of determination of 15 elements in honey with chemometric approach for the verification of their authenticity. Food and Chemical Toxicology, 49(11), 2741-2749. https://doi.org/10.1016/i.fct.2011.08.014

18. 18.Tochilina, R. P., Goncharova, S. A., Horosheva, E. V., Semipjatnyj, V. K. (2016). Characteristic of the Mineral Composition Don Wines and Wine Materials Identification as an Indicator of the Place of Origin. Wine-Making Industry and Viticulture, 3,14-17. (in Russian)

19. 19.Tochilina, R. P. (2017). Characteristic of the Wines Mineral Composition as an Indicator of the Place of Origin (Krasnodar Region). Beer and beverages, 5, 28-32. (in Russian)

20. Drivelos, S.A., Georgiou, C.A. (2012). Multi-element and multi-isotoperatio analysis to determine the geographical origin of foods in the European Union. TrAC - Trends in Analytical Chemistry, 40, 38-51. https://doi org/10.1016/j.trac.2012.08.003

21. Paleologos, E. K., Kontominas, M. G. (2007). Effect of processing and storage conditions on the generation of acrylamide in precooked breaded chicken products. Journal of Food Protection, 70(2), 466-470. https://doi. org/10.4315/0362-028x-70.2.466

22. Parati, K., Bongioni, G., Aleandri, R., Galli, A. (2006). Sex ratio determination in bovine semen: A new approach by quantitative real time PCR. Theriogenology, 66(9), 2202-2209. https://doi.org/10.1016/j.theriogenology.2006.07.007

23. Oganesyants, L. A., Panasyuk, A. L., Kuzmina, E. I., Sviridov D. A. (2019) Use of the modern instrumental analysis methods for establishing geographical place of wine product origin. Beer and beverages, 4, 59-64. https://doi.org/10.24411/2072-9650-2019-10002 (in Russian)

24. Ayaz, Y., Ayaz, N.D., Erol, I. (2006). Detection of species in meat and meat products using enzyme-linked immunosorbent assay. Journal of Muscle Foods, 17(2), 214-220. https://doi.org/10.1111/j.17454573.2006.00046.x

25. Bahar, B., Schmidt, O., Moloney, A.P., Scrimgeour, C.M., Begley, I.S., Monahan, F.J. (2008). Seasonal variation in the C, N and S stable isotope composition of retail organic and conventional Irish beef. Food Chemistry, 106(3), 1299-1305. https://doi.org/10.1016/j.foodchem.2007.07.053

26. Ballin, N.Z., Lametsch, R. (2008). Analytical methods for authentication of fresh vs. thawed meat - A review. Meat Science, 80(2), 151-158. https://doi.org/10.1016/j.meatsci.2007.12.024

27. Ballin, N.Z., Madsen, K.G. (2007). Sex determination in beef by melting curve analysis of PCR amplicons from the amelogenin locus. Meat Science, 77(3), 384-388. https://doi.org/10.1016/j.meatsci.2007.04.029

28. Ballin, N.Z., Vogensen, F.K., Karlsson, A.H. (2009). Species determination - Can we detect and quantify meat adulteration? Meat Science, 83(2), 165-174. https://doi.org/10.1016/j.meatsci.2009.06.003 
29. Chernukha, I., Yurchak, Z., Kuzmina, E. (2018). Study on the meat isotopick composition for origin identification. Potravinarstvo Slovak Journal of Food Sciences, 12(1), 262-266. https://doi.org/10.5219/906

30. Gorbunova, N.A. (2018). Possibilities of using stable isotopes for identification of geographical origin of meat and meat products. A review. Theory and Practice of Meat Processing, 3(1), 46-58. https://doi. org/10.21323/2414-438X-2018-3-1-46-58 (in Russian)

31. Piasentier, E., Valusso, R., Camin, F., Versini, G. (2003). Stable isotope ratio analysis for authentication of lamb meat. Meat Science, 64(3), 239247. https://doi.org/10.1016/S0309-1740(02)00183-3

32. Liu, X., Guo, B., Wei, Y., Shi, J., Sun, S. (2013). Stable isotope analysis of cattle tail hair. A potential tool for verifying the geographical origin of beef. Food Chemistry, 140(1-2), 135-140. https://doi.org/10.1016/j.foodchem.2013.02.020

33. Kim, K.S., Kim, J.S., Hwang, I.M., Jeong, I.S., Khan, N., Lee, S.I., Jeon, D.B., Song, Y.H., Kim, K.S., (2013). Application of stable isotope ratio analysis for origin authentication of pork. Korean Journal for Food Science of Animal Resources, 33(1), 39-44. https://doi.org/10.5851/kosfa.2013.33.1.39

34. Ballin, N.Z. (2010). Authentication of meat and meat products. Meat Science, 86(3), 577-587. https://doi.org/10.1016/j.meatsci.2010.06.001

35. Monahan, F.J., Schmidt, O., Moloney, A.P. (2018). Meat provenance: Authentication of geographical origin and dietary background of meat. Meat Science, 144, 2-14. https://doi.org/10.1016/j.meatsci.2018.05.008

36. Horacek, M., Eisinger, E., Papesch, W. (2010). Reliability of stable isotope values from meat juice for the determination of the meat origin. Food Chemistry, 118(4), 910-914. https://doi.org/10.1016/j.foodchem.2009.03.090

37. Franke, B.M., Hadorn, R., Bosset, J.O., Gremaud, G., Kreuzer, M. (2008). Is authentication of the geographic origin of poultry meat and dried beef improved by combining multiple trace element and oxygen isotope analysis? Meat Science, 80(3), 944-947. https://doi.org/10.1016/j.meatsci.2008.03.018

38. Franke, B.M., Haldimann, M., Gremaud, G., Bosset, J. O., Hadorn, R., Kreuzer, M. (2008). Element signature analysis: its validation as a tool for geographic uthentication of the origin of dried beef and poultry meat. European Food Research and Technology, 227(3), 701-708. https://doi. org/10.1007/s00217-007-0776-8

39. Dawson, T. E., Brooks, P. D. (2001). Fundamentals of stable isotopic chemistry and measurement. In book: Stable isotope techniques in the study of biological processes and functioning of ecosystems. Springer Science+Business Media B. V. 1-18 ISBN: 978-90-481-5736-5

40. Capuano, E., Rademaker, J., van den Bijgaart, H., M. van Ruth, S. (2014). Verification of fresh grass feeding, pasture grazing and organic farming by FTIR spectroscopy analysis of bovine milk. Food Research International, 60, 59-65. https://doi.org/10.1016/j.foodres.2013.12.024

41. Liu, N., Koot, A., Hettinga, K., de Jong, J., van Ruth, S.M. (2018). Portraying and tracing the impact of different production systems on the volatile organic compound composition of milk by PTR-(Quad)MS and PTR-(ToF)MS. Food Chemistry, 239, 201-207. https://doi.org/10.1016/j. foodchem.2017.06.099

42. Soyeurt, H., Dardenne, P., Dehareng, F., Lognay, G., Veselko, D., Marlier, M., Bertozzi, C., Mayeres, P., Gengler, N. (2006). Estimating fatty acid content in cow milk using mid-infrared spectrometry. Journal of Dairy Science, 89(9), 3690-3695. https://doi.org/10.3168/jds.S00220302(06)72409-2

43. Coppa, M., Ferlay, A., Chassaing, C., Agabriel, C., Glasser, F., Chilliard, Y., Borreani, G., Barcarolo, R., Baars, T., Kusche, D., Harstad, O.M., Verbič, J., Golecký, J., Martin, B. (2013). Prediction of bulk milk fatty acid composition based on farming practices collected through on-farm surveys. Journal of Dairy Science, 96(7), 4197-4211. https://doi.org/10.3168/ jds.2012-6379

44. Delgadillo-Puga, C., Sánchez-Muñoz, B., Nahed-Toral, J., Cuchillo-Hilario, M., Díaz-Martínez, M., Solis-Zabaleta, R. Reyes-Hernández, A., Castillo-Domíguez, R.M. (2014). Fatty acid content, health and risk indices, physicochemical composition, and somatic cell counts of milk from organic and conventional farming systems in tropical south-eastern Mexico. Tropical Animal Health and Production, 46(5), 883-888. https://doi. org/10.1007/s11250-014-0581-x

45. Rossmann, A., Haberhauer, G., Hölzl, S., Horn, P., Pichlmayer, F., Voerkelius, S. (2000). The potential of multielement stable isotope analysis for regional origin assignment of butter. European Food Research and Technology, 211(1), 32-40. https://doi.org/10.1007/s002170050585

46. Crittenden, R.G., Andrew, A.S., LeFournour, M., Young, M.D., Middleton, H., Stockmann, R. (2007). Determining the geographic origin of milk in Australasia using multi-element stable isotope ratio analysis. International Dairy Journal, 17(5), 421-428. https://doi.org/10.1016/j.idairyj.2006.05.012
47. Scampicchio, M., Eisenstecken, D., De Benedictis, L., Capici, C., Ballabio, D., Mimmo, T., Robatscher, P., Kerschbaumer, L., Oberhuber, M., Kaser, A. Huck, C.W. Cesco, S. (2016). Multi-method Approach to Trace the Geographical Origin of Alpine Milk: a Case Study of Tyrol Region. Food Analytical Methods, 9(5), 1262-1273. https://doi.org/10.1007/s12161$015-0308-2$

48. Huang, J., Norgbey, E., Nkrumah, P.N., Appiah-Sefah, G., Michel, R. (2017). Elucidating the origin of milk products on the Chinese market using hydrogen and oxygen stable isotope technique. Integrative Food, Nutrition and Metabolism, 4(3). https://doi.org/10.15761/IFNM.1000184

49. Camin, F., Perini, M., Colombari, G., Bontempo, L., Versini, G. (2008) Influence of dietary composition on the carbon, nitrogen, oxygen and hydrogen stable isotope ratios of milk. Rapid Communications in Mass Spectrometry, 22(11), 1690-1696. https://doi.org/10.1002/rcm.3506

50. Potočnik, D., Nečemer, M., Mazej, D., Jaćimović, R., Ogrinc, N. (2016). Multi-elemental composition of Slovenian milk: Analytical approach and geographical origin determination. Acta IMEKO, 5(1), 15-21.

51. Chung, I.-M., Kim, J.-K., Yang, Y.-J., An, Y.-J., Kim, S.-Y., Kwon, C., Kim, S.-H. (2020). A case study for geographical indication of organic milk in Korea using stable isotope ratios-based chemometric analysis. Food Control, 107, 106755. https://doi.org/10.1016/j.foodcont.2019.106755

52. Roshan, A.-R.A., Gad, H.A., El-Ahmady, S.H., Abou-Shoer, M.I., Khanbash, M.S., Al-Azizi, M.M. (2017). Characterization and discrimination of the floral origin of sidr honey by physicochemical data combined with multivariate analysis. Food Analytical Methods, 10(1), 137-146. https://doi. org/10.1007/s12161-016-0563-x

53. Bastías, J.M. Jambon, P. Muñoz, O., Manquián, N., Bahamonde, P., Neira, M. (2013): Honey as a bioindicator of arsenic contamination due to volcanic and mining activities in Chile. Chilean Journal of Agricultural Research, 73(2), 147-153. https://doi.org/10.4067/S0718-58392013000200010

54. Benedetti, S., Mannino, S., Sabatini, A.G., Marcazzan, G.L. (2004). Electronic nose and neural network use for the classification of honey. Apidologie, 35(4), 397-402. https://doi.org/10.1051/apido:2004025

55. Cordella, C., Faucon, J.-P., Cabrol-Bass, D., Sbirrazzuoli, N. (2003). Application of DSC as a tool for honey floral species characterization and adulteration detection. Journal of Thermal Analysis and Calorimetry, 71(1) 279-290.

56. Radovic, B.S., Goodacre, R., Anklam, E. (2001). Contribution of pyrolysismass spectrometry (Py-MS) to authenticity testing of honey. Journal of Analytical and Applied Pyrolysis, 60(1), 79-87. https://doi.org/10.1016/ S0165-2370(00)00163-7

57. Goodacre, R., Radovic, B.S., Anklam, E. (2002). Progress toward the rapid nondestructive assessment of the floral origin of European honey using dispersive Raman spectroscopy. Applied Spectroscopy, 56(4), 521-527. https://doi.org/10.1366/0003702021954980

58. Davies, A.M.C., Radovic, B., Fearn, T., Anklam, E. (2002). A preliminary study on the characterisation of honey by near infrared spectroscopy. Journal of Near Infrared Spectroscopy, 10(2), 121-135. https://doi. org/10.1255/jnirs.329

59. Kek, S.P., Chin, N.L., Tan, S.W., Yusof, Y.A., Chua, L.S. (2004). Classification of honey from its bee origin via chemical profiles and mineral content. Food Analytical Methods, 10(1), 19-30. https://doi.org/10.1007/ s12161-016-0544-0

60. Tucak, Z., Periškić, M., Bešlo, D., Tucak, I. (2004). Influence of the beehive type on the quality of honey. Collegium Antropologicum, 28(1), 463-467.

61. Batelková, P., Borkovcová, I., Čelechovská, O., Vorlová, L., Bartáková, K. (2012): Polycyclic aromatic hydrocarbons and risk elements in honey from the South Moravian region (Czech Republic). Acta Veterinaria Brno, 81(2), 169-174. https://doi.org/10.2754/avb201281020169

62. Schellenberg, A., Chmielus, S., Schlicht, C., Camin, F., Perini, M., Bontempo, L., Heinrich, K., Kelly, S.D., Rossmann, A., Thomas, F., Jamin E., Horacek, M. (2010) Multielement stable isotope ratios (H, C, N, S) of honey from different European regions. Food Chemistry, 121(3), 770-777. https://doi.org/10.1016/j.foodchem.2009.12.082

63. Wang, J., Kliks, M.M., Qu, W., Jun, S., Shi, G., Li, Q.X. (2009). Rapid determination of the geographical origin of honey based on protein fingerprinting and barcoding using MALDI TOF MS. Journal of Agricultural and Food Chemistry, 57(21), 10081-10088. https://doi.org/10.1021/jf902286p

64. Kropf, U., Korošec, M., Bertoncelj, J., Ogrinc, N., Nečemer, M., Kump, P., Golob, T. (2010). Determination of the geographical origin of Slovenian black locust, lime and chestnut honey. Food Chemistry, 121(3), 839-846. https://doi.org/10.1016/j.foodchem.2009.12.094

65. Bora, F.D., Donici, A., Rusu, T., Bunea, A., Popescu, D., Bunea, C.I. (2018). Elemental profile and ${ }^{207} \mathrm{~Pb} /{ }^{206} \mathrm{~Pb},{ }^{208} \mathrm{~Pb} /{ }^{206} \mathrm{~Pb},{ }^{204} \mathrm{~Pb} /{ }^{206} \mathrm{~Pb},{ }^{87} \mathrm{Sr} /{ }^{86} \mathrm{Sr}$ isotope ratio as fingerprints for geographical traceability of Romanian wines. Notulae Botanicae Horti Agrobotanici Cluj-Napoca, 46(1), 223-239. https://doi.org/10.15835/nbha46110853

\section{AUTHOR INFORMATION}

Lev A. Oganesyants - doctor of technical sciences, professor, academician of RAS, Director, All-Russian Scientific Research Institute of Brewing, Beverage and Wine Industry - Branch of V. M. Gorbatov Federal Research Center for Food Systems of RAS, 119021, Moscow, Rossolimo str., 7 Tel.: +7-499-246-67-69, E-mail: vniipbivp@fncps.ru

ORCID: https://orcid.org/0000-0001-8195-4292 
Alexander L. Panasyuk - doctor of technical sciences, professor, deputy Director, All-Russian Scientific Research Institute of Brewing, Beverage and Wine Industry - Branch of V. M. Gorbatov Federal Research Center for Food Systems of RAS, 119021, Moscow, Rossolimo str., 7, Tel.: +7-499-246-76-38

E-mail: alpanasyuk@mail.ru

ORCID: https://orcid.org/0000-0002-5502-7951

Elena I. Kuzmina - candidate of technical sciences, head of the laboratory of technology of grape and fruit wines, All-Russian Scientific Research Institute of Brewing, Beverage and Wine Industry - Branch of V. M. Gorbatov Federal Research Center for Food Systems of RAS, 119021, Moscow, Rossolimo str., 7, Tel. +7-499-246-62-75, E-mail: labvin@yandex.ru

*corresponding author

ORCID: https://orcid.org/0000-0001-7623-440X

Dmitriy A. Sviridov - candidate of technical sciences, scientist of the laboratory of technology of grape and fruit wines, All-Russian Scientific Research Institute of Brewing, Beverage and Wine Industry - Branch of V. M. Gorbatov Federal Research Center for Food Systems of RAS, 119021, Moscow, Rossolimo str., 7, Tel.: +7-499-246-62-75, E-mail: labvin@yandex.ru

ORCID: https://orcid.org/0000-0001-8367-3523

All authors bear responsibility for the work and presented data.

All authors made an equal contribution to the work.

The authors were equally involved in writing the manuscript and bear the equal responsibility for plagiarism.

The authors declare no conflict of interest.

Received 11.11.2019 Accepted in revised 14.02.2020 Accepted for publication 21.02.2020 